Bulletin d'Histoire Contemporaine de

I'Espagne

$54 \mid 2020$

Les espaces du politique dans l'Espagne du Trienio liberal (1820-1823)

\title{
Ángeles EGIDO LEÓN (ed.), Cárceles de mujeres. La prisión femenina en la posguerra
}

\section{Sergio NIEVES CHAVES}

\section{(2) OpenEdition}

\section{Journals}

Edición electrónica

URL: http://journals.openedition.org/bhce/3197

DOI: 10.4000/bhce.3197

ISSN: 1968-3723

\section{Editor}

Presses Universitaires de Provence

\section{Edición impresa}

Fecha de publicación: 1 enero 2020

ISSN: 0987-4135

\section{Referencia electrónica}

Sergio NIEVES CHAVES, « Ángeles EGIDO LEÓN (ed.), Cárceles de mujeres. La prisión femenina en la posguerra », Bulletin d'Histoire Contemporaine de l'Espagne [En línea], 54 | 2020, Publicado el 01 julio 2020, consultado el 01 enero 2021. URL : http://journals.openedition.org/bhce/3197 ; DOI : https:// doi.org/10.4000/bhce.3197

Este documento fue generado automáticamente el 1 enero 2021.

Bulletin d'histoire contemporaine de l'Espagne 


\title{
Ángeles EGIDO LEÓN (ed.), Cárceles de mujeres. La prisión femenina en la posguerra
}

\author{
Sergio NIEVES CHAVES
}

\section{REFERENCIA}

Ángeles EGIDO LEÓN (ed.), Cárceles de mujeres. La prisión femenina en la posguerra.

Alcorcón: Sanz y Torres, 2017, 439 pp.

1 La evaluación de la violencia política ejercida sobre las mujeres durante la guerra y la inmediata posguerra ha sido la gran asignatura pendiente en los estudios generales de la represión franquista. La invisibilidad femenina que en tantas ocasiones ha denunciado la historiografía de género al respecto ha permanecido casi inalterable hasta finales de los años noventa del siglo pasado, si bien desde entonces se han producido importantes avances en el estudio de la naturaleza, la tipificación y la cuantificación de dicha violencia. Asimismo, la investigación a pequeña escala ha posibilitado esclarecer las connotaciones propias de la experiencia vital y carcelaria de las mujeres represaliadas y obtener resultados de mayor beneplácito historiográfico.

2 En este ambiente de despegue se encuadra la obra editada por la Catedrática de Historia Contemporánea de la UNED, Ángeles Egido León. Se trata de una edición revisada y ampliada del doble número monográfico de la revista Studia Histórica. Historia Contemporánea publicado en 2011. Dado el gran interés que despertó su presentación en el Ateneo de Madrid un año después, condujo a los autores a publicar las investigaciones en un libro con un carácter más divulgativo y accesible al gran público. Cárceles de mujeres. La prisión femenina en la posguerra recopila un total de catorce estudios realizados por especialistas en la materia con un denominador común: reconstruir la vida de las mujeres y las de sus hijos menores de tres años en el interior de las cárceles franquistas. 
3 Fundamentalmente, la experiencia carcelaria de las presas del franquismo se ha conocido gracias a los testimonios y memorias de las propias reclusas, siendo ello buena muestra del discurso de resistencia antifranquista. Así, durante largo tiempo se erigieron como principal y casi único soporte del que partir para explicar la sistemática persecución que sufrieron y la horrible vida a la que se vieron sometidas. En este sentido, el libro va más allá y en su rigurosa metodología emplea, además, fuentes orales y documentación de archivo que comprende padrones y expedientes carcelarios y judiciales. Todo ello, unido al uso contrastado de la abundante bibliografía referente al tema, hace del libro una excepcional puesta al día. El análisis minucioso de estas fuentes aporta nuevas claves explicativas tanto en lo que se refiere al discurso represivo como a las singularidades específicas de esa represión diferenciada por cuestión de género que el régimen les reservó.

El libro traza un itinerario por distinguidas prisiones femeninas de la geografía española del que se puede extraer, además de los puntos en común de hacinamiento, insalubridad y hambre, los hechos distintivos y las peculiaridades propias de cada una de ellas. Los perfiles de las procesadas, la tipología de los delitos que se les atribuyeron, el dramático caso de los niños, la presencia de la Iglesia, la vida cotidiana o la formación política y cultural, son otros de los asuntos que se analizan para cumplir con el objetivo principal. Paralelamente, a lo largo de la obra el lector también podrá conocer cómo evolucionó la industria penitenciaria franquista y la trasformación de las circunstancias carcelarias de las anteriores y las posteriores. De igual modo, y aún más llamativo si cabe, cómo se fue forjando la cultura carcelaria de unas presas que fueron capaces de construir, en medio de una adversa coyuntura, todo un mecanismo de resistencia, supervivencia y solidaridad.

5 En el primero de los artículos, a modo de presentación, Ángeles Egido examina la condición femenina como fundamento del sistema represor, resaltando que la femenina fue una represión diferenciada. A continuación, Ricard Vinyes estudia los cambios producidos en el sistema penitenciario femenino y el perfil de las encarceladas políticas. El examen de las prisiones valencianas, en especial la del Convento de Santa Clara, corre a cargo de Ana Aguado y Vicenta Verdugo, mientras que el de las gallegas viene dado por María Victoria Martins Rodríguez. Por su parte, las precursoras en los estudios de represión de género, Encarnación Barranquero y Matilde Eiroa, realizan un balance de las "marxistas peligrosas" que estuvieron en la cárcel provincial de Málaga. Seguidamente, Iván Heredia Urzáiz se sumerge en la prisión de Torrero, Zaragoza, con una concisa síntesis sobre la geografía de las mujeres encerradas, las vicisitudes que sufrieron en su interior y el drama de sus hijos. El tema de los niños también es tratado, con especial interés, por Rosa María Aragüés quien centra su mirada en los niños de la cárcel de Predicadores y resalta un tema tan espinoso como la adopción ilegal.

6 En el octavo de los estudios, Fernando Fernández Holgado realiza un exhaustivo seguimiento de las dos prisiones militantes más representativas de la posguerra, Ventas y Les Corts. El castigo y la redención de las mujeres encarceladas en las Baleares es tarea de David Ginard i Ferón quien, además, analiza la figura de Matilde Landa, reconocida dentro de la prisión por su insaciable lucha contra el nuevo régimen. Miren Arantza Ugarte aborda las vivencias de las mujeres destinadas a la prisión de Saturrarán, mientras que Santiago Vega y Juan Carlos García se introducen en la prisión central de mujeres de Segovia, conocida por sus duras condenas y la labor testimonial que ya en la década de 1980 efectuó Tomasa Cuevas, presa de la misma. El recorrido por 
los centros penitenciarios femeninos españoles se cierra con un estudio de caso relativo a las cárceles de Tarragona, de la mano de Montserrat Duch. Finalmente, la obra concluye con dos investigaciones que aluden a las prisiones portuguesas e italianas de mujeres en el contexto de las dictaduras de Salazar y de Mussolini, respectivamente.

7 Se trata, en definitiva, de una obra que ensambla Historia y Memoria y que responde a la solidez metodológica y la serenidad analítica a las que debe atenerse todo historiador. Además, enfatiza en aspectos menos conocidos o que han pasado desapercibidos dentro del mundo académico hasta la fecha, permitiendo así profundizar en el conocimiento del fenómeno carcelario femenino. Constituye, por tanto, un trabajo excepcional y necesario en la medida que contribuye a visibilizar, difundir y ampliar las particularidades represivas que se obraron sobre aquellas mujeres que, por su doble condición de "roja" y "mujer", fueron castigadas.

\section{AUTORES}

\section{SERGIO NIEVES CHAVES}

Universidad de Castilla-La Mancha 